\title{
TNFRSF10C wt Allele
}

National Cancer Institute

\section{Source}

National Cancer Institute. TNFRSF10C wt Allele. NCI Thesaurus. Code C104516.

Human TNFRSF10C wild-type allele is located within 8p22-p21 and is approximately $48 \mathrm{~kb}$ in length. This allele, which encodes tumor necrosis factor receptor superfamily member $10 \mathrm{C}$ protein, plays a role in both apoptosis inhibition and lig and binding. 